\title{
Eros Tyrannos: Alcibiades as the Model of the Tyrant in Book IX of the Republic
}

\author{
Annie Larivée \\ Carleton University, Ottawa, Ontario, Canada \\ annielarivee@carleton.ca
}

\begin{abstract}
The aim of this article is to make use of recent research on 'political eros' in order to clarify the connection that Plato establishes between eros and tyranny in Republic IX, specifically by elucidating the intertextuality between Plato's work and the various historical accounts of Alcibiades. An examination of the lexicon used in these accounts will allow us to resolve certain interpretive difficulties that, to my knowledge, no other commentator has elucidated: why does Socrates blame eros for the decline from democracy into tyranny? What does he mean by 'eros' here, and what link existed between eros and tyranny in the minds of his contemporaries? And finally, who are the mysterious 'tyrant-makers' (turannopoioi, 572e5-6) who, according to Socrates, introduce a destructive eros in the soul of the future tyrant? After a careful examination of the passage from book IX on the genesis of the tyrannical man (focused on the last stage of the metamorphosis, which is concerned with éros túrannos, 572d-573b), I will offer answers to these questions by turning to the writings of Thucydides, Aristophanes and Plutarch while examining the portrait of Alcibiades that Plato paints in the Alcibiades I and Symposium.
\end{abstract}

\section{Keywords}

eros, tyranny, Alcibiades, paranomia

On oublie Alcibiade, mais les questions qu'avait fait naître sa vie continuent de progresser au cœur du platonisme. On pourrait même dire, à la limite, que ce qui peut paraître excessif, dans la rigueur de la cité platonicienne, peut s'expliquer par l'horreur de voir renaître dans une cité des Alcibiade...'

\footnotetext{
1) De Romilly (1995), 246. "We forget Alcibiades, but the questions that arise from his life reach right to the core of Platonism. We might even say, to a certain extent, that what seems 
According to Julia Annas the portrait of the tyrant that Plato paints in book IX is a weak point in the Republic. In her view, this portrait possesses neither psychological realism nor political relevance insofar as the kind of tyrant depicted here "would not last a week". Thus Annas does not accept the comparison to Dionysus I of Syracuse, arguing that the character described by Socrates pertains more to a "psychopathically dissolving personality" like that of Caligula than to a "tough-minded dictator like Dionysus I, clever and effective in gaining and keeping power". "Most real successful dictators," she explains, "have in fact been (like Lenin and Stalin) tireless bureaucrats with conventional opinions and unimaginative private lives." ${ }^{2}$ Although Annas' diagnosis is anachronistic, ${ }^{3}$ it does, however, bring to light the disconcerting character of the passage from book IX where Plato attributes the genesis of the tyrant to the influence of eros. Indeed, it is true that from a contemporary point of view this passage is hardly convincing, not to say unintelligible. However, given the quantity and the quality of research recently endeavoured by historians of antiquity concerning the close connection between eros, democracy and tyranny-notably the works of Paul Ludwig and Victoria Wohl—-the interpreters of the Republic

excessive to us in the rigors of the Platonic state can be explained by the horror of seeing Alcibiades reborn in a city" [my translation]. A short version of this article was presented at the IXth Symposium Platonicum in Tokyo, in the summer of 2010. The questions posed by Aikatérini Lefka, Arnaud Macé, and Gérard Naddaf have allowed me to clarify my thought, and I thank them. I also want to thank Iain Laidley in particular as well as the two anonymous referees of the JPT, whose comments have proven to be extremely helpful in the revision of this article. Finally, I would also like to express my gratitude to Patrick Eldridge for his help in the translation and final editing of this text.

2) Annas (1981), 304. I reject, like Annas (though for different reasons), the comparison of the tyrant of Rep. IX to Dionysus I, as described in Letter VII. The difference is that whereas Letter VII is concerned with an already established tyrant, Rep. IX is about the genesis of the tyrannical soul, a genesis of which nothing is said in Letter VII. Furthermore, while the tyrants described in Letter VII remain on the whole measured (which explains how Plato could have believed in the possibility of converting Dionysus II), the tyrannical soul of Rep. IX is such a monstrosity that all hope for conversion seems to be excluded a priori. The question posed by Rep. IX is prior to that of Letter VII: there is no concern for converting a tyrant to philosophy, but to ensure that the tyrannical lifestyle is never an object of choice. A deeper comparison of the figure of the tyrant in these two texts would require a separate study.

3) Ancient tyranny is not modern totalitarianism. See the historical overview given by

R. Boesche (1996) which allows us to grasp the differences of the phenomena at stake. 
have no excuse for leaving the question of eros tyrannos in the dark or for offering anachronistic interpretations. The aim of my text is simple: to make use of recent research on 'political eros $^{\text {' }}$ in order to clarify the connection that Plato establishes between eros and tyranny, specifically by elucidating the intertextuality between Plato's work and the various historical accounts of Alcibiades. An examination of the lexicon used in these accounts will allow us to resolve certain interpretive difficulties that, to my knowledge, no other commentator has elucidated: why does Socrates blame eros for the decline from democracy into tyranny? What does he mean by eros here and what link existed between eros and tyranny in the minds of his contemporaries? And finally, who are the mysterious "tyrantmakers" (turannopoioi, 572e5-6) who, according to Socrates, introduce a destructive eros in the soul of the future tyrant? After a careful examination of the passage from book IX on the genesis of the tyrannical man (focused on the last stage of the metamorphosis, which is concerned with éros túrannos, $572 \mathrm{~d}-573 \mathrm{~b}$ ), I will offer answers to these questions by turning to the writings of Thucydides, Aristophanes and Plutarch while examining the portrait of Alcibiades that Plato paints in the Alcibiades I and Symposium.

\section{The Enigmatic Role of Eros in the Genesis of the Tyrant}

Let us begin by recalling the central elements of the democratic man's metamorphosis into the tyrannical man. According to the description in book VIII, even if the life of the democratic man is primarily dedicated to the fulfillment of unnecessary desires, the influence of an oligarchic father opposes the appeal of paranomía, i.e.: transgressive, illegal—read: monstrous- desires. ${ }^{5}$ Whereas the democratic man was shielded by his oligarchic father, the democratic man's son will receive no protection from the machinations of the "tyrant-makers" (turannopoioi ). They will stir within

\footnotetext{
4) I borrow this expression from Ludwig (2002), 10. It also appears in Newell (2000), 2.

5) The paránomoi desires are those which "awake during sleep" (571c3), particularly when the "brutish and savage" part of the soul has been inflated due to an excess of food and drink. They border on horror and transgress taboos: the desire for incest, rape, and bestiality (the desire to "rape his mother or any other, be they man, god or animal"), desire for murder, cannibalism; see $571 \mathrm{di}-4 . C f$. 574-2-5. All references to Plato's Republic will be from the Reeve (2004) translation. Unless mentioned otherwise, reference to all other Platonic dialogues will be from Plato Complete Works, (1997) Cooper ed.
} 
the son's soul a certain eros which will be the source of his metamorphosis into the tyrannical man:

Suppose, too, that the same things happen to him as happened to his father: he is led into all the kinds of lawlessness (eis pâsan paranomian) that those leading him call total freedom. His father and the rest of his family come to the aid of the appetites that are in the middle, while the others help the opposite ones. And when these terrible enchanters and tyrant-makers (hoi deinoi mágoi te kai turannopoioi ), have no hope of keeping hold of the young man in any other way, they contrive to implant a powerful passion in him (érotá tina autôi $i$ mechanoménous empoiêsai) as the popular leader of those idle and profligate appetites (prostáten tônn argônn kai tà hétoima dianemoménon epithumiôn)—a sort-of great, winged drone (...) And when the other appetites come buzzing around (...) they feed the drone and make it grow as large as possible, and plant the sting of longing in it (póthou kéntron empoiésosi tôi kẹphêni). Then this popular leader of the soul (hoûtos ho prostátes têes psuchêes) adopts madness as its bodyguard and is stung to frenzy. $(572 \mathrm{~d}-573 \mathrm{~b})$

In a recent article dedicated to the figure of the tyrant in the Republic, Richard Parry highlights the mysterious character of the intervention of eros at this point in the text. ${ }^{6}$ Before investigating its object, let us quickly describe its effects. With the appearance of eros, the thorn of desire (póthos), puts an end to the listless dispersion of the democratic man:7 "tyrannical eros, established inside, takes control of all things relating to the soul" (éros túrannos éndon oikôn diakubernâi tà tệs psuchêes hápanta, 573d4-5). Eros intensifies the desires by uniting them under its command and it is this concentrated, insatiable voracity that leads the young man to the worst excesses and transgressions (paranomía). ${ }^{8}$ As such, the tyrannical man proves himself to be formidable because he is strained, unified and obsessed by a dominating passion. ${ }^{9}$ The effects of eros seem clear, but the passage

\footnotetext{
6) "... the eros in question seems to be sexual, although it is hard to say what the object of this eros is", Parry (2007), 395. Scott (2007), 140, emphasizes that "the tyrant-makers engender a specific kind of desire that has a unique capacity to transform the soul", but he does not explain what this transformative eros consists in.

7) "Pothos is the special name for the desire of what is distant. Love in absence is the brother of Love in presence, Himeros", Cornford (1965), 215. Cf. Crat., $420 a$.

8) Paranomic desires, paranomia, are mentioned in $571 \mathrm{~b}, 572 \mathrm{~b}$, d, e.

9) For a more detailed description of this metamorphosis, see Larivée (2005), 177-83.
} 
cited above nevertheless gives rise to several questions largely overlooked by interpreters.

To start, what does 'eros' designate here and what is its object? And who are these "tyrant-makers" that introduce eros into the soul of the young democratic man? Is it simply a matter of them arousing a romantic passion within him? It is possible; however, insofar as the Greek term 'eros' does not solely signify love in the sense of a sexual attraction, but designates an intense desire that can apply to all sorts of actions and objects (from the most sublime to the most trivial), other interpretations should be considered. ${ }^{10}$ Indeed, if the term eros designates a romantic passion, what could Socrates mean when he explains that the turannopoioi "plant in him [the young man] a certain eros" (572e6-7)? Is it really possible to arouse in someone a passion for someone else? And what interest would these 'tyrantmakers' have in generating this type of obsession? If they hope to take advantage of their relationship with him, they have everything to lose if the young man becomes absorbed in a lover to whom he dedicates his resources. ${ }^{.1}$ Could eros designate rather a general voracity for carnal pleasures or a more egotistical passion: a violent desire for conquest, for example, an insatiable appetite for glory, an intense political ambition? In fact, in the passage on eros tyrannos, these two senses of eros (the thumoeidetic and the epithumetic senses) are not only compatible, but strongly complementary. Their perfect fusion is attested to by Socrates' most flamboyant and scandalous disciple: Alcibiades. I will now demonstrate how the accounts of Thucydides, Aristophanes and Plutarch provide us with an invaluable key for interpreting the development of eros' role in the genesis of the tyrannical man.

\footnotetext{
10) On the basis of a thorough lexical study, Côté (1997), 5-6, concludes that: "éros denotes primarily a psychological passion, rather than a physical desire". Ludwig (2002), 8, has also criticized "the tendency of recent scholarship ... to reduce the meaning of eros ... to sexual desire"; on the specificity of the ancient sense of eros, see 7-13, and for a diachronic semantic study, see 121-169. His insistence on the necessity of perceiving beauty in the object of eros leads Ludwig to neglect tyrannical eros though. While it is true that he has dedicated a section to the hubristic manifestations of eros, this aspect does not enter into his analysis of "political eros" that is centered on the following themes: 1) political pederasty, 2) civic friendship, 3) the city as an object of eros, see 19.

i1) According to Ludwig (2007), 224, "the beloved is only a catalyst".
} 


\section{The Tyrant and His Erotic Omnipotence}

Before calling to mind this "personified eros" that was Alcibiades, ${ }^{12}$ a few words on the obvious link that the ancients - particularly the Atheniansperceived between a certain erotic voraciousness and the political phenomenon of tyranny. Xenophon's Hiero, of which an important part (I, 33-38) is concerned with the erotic advantages that the tyrant enjoys, is particularly enlightening. "It is probable that the enjoyment of sex (...), comes dangerously close to producing desires for tyranny," Simonides suggests to his interlocutor, the tyrant Hiero, "[f] or there, it is possible for you to have intercourse with the fairest you see". ${ }^{13}$ This passage shows that in the eyes of the ancients, one of the principal advantages of tyrannical power consisted in treating anyone as an object of sexual pleasure, completely free of restraint: "Tyranny represents a mode of desire within politics: politics as libido" writes V. Wohl. ${ }^{14}$ This connection also appears in the famous story of the two heroic tyrannicides Harmodius and Aristogeiton, responsible for the murder of the tyrant Hipparchus, son of Peisistratus, who was taken with Harmodius. ${ }^{15}$ As Wohl notes, this story, that brings together paiderastia, tyrannicidal revolt, and the advent of a new egalitarian political order, functions as a "foundation myth" in the eyes of Athenian democrats. $^{16}$ Harmodius and Aristogeiton, whose love brought "[the tyrants'] reign to a dismal end" (Symposium, 182c), were deemed worthy of having a statue in their honour placed in the agora and became the object of a

12) Expression used by Strauss (1993), 152, cited by Wohl (1999), 352. This trait clearly brings Alcibiades close to the figure of Socrates, the demonic expert in all things concerning eros, see Symposium, $177 \mathrm{~d}$.

13) Hiero, I, 26. Cf. Strauss (2000), 96.

14) Wohl (2002), 221.

15) Following Thucydides' version, which Plato echoes in his Symposium (182c), Aristogeiton wanted to protect his eromenos Harmodius from the advances of Hipparchus, fearing that "given his power, Hipparchus might take Harmodius and rape him". The erastes then developed a plan to "combat tyranny," taking advantage of the Panathenaea to accomplish his audacious plot with the help of Harmodius. Thucydides tells us that: "they jumped him, instantly and without a moment's thought, and with a rage that only a jealous lover and a man stung by insult could feel, they stabbed him repeatedly and killed him". One perished immediately and the other, who managed to escape, was later captured and executed. See The Peloponnesian War, VI, 54-59. Cf. Herodotus, V, 55-57; VI, 123.

16) Wohl (2002), 3 . 
quasi-cult in Athens. ${ }^{17}$ In fact, as many texts reveal, the supporters of democracy were victim to a form of paranoia that a new tyrant would appear. ${ }^{18}$ And insofar as tyranny was associated with a tendency to use political power for the sake of erotic ends, in their eyes, the presence of unbridled passions in a political leader was sufficient to cast suspicion over him and to stir accusations of tyrannical ambitions against him. This erotico-tyrannical paranoia may well explain why Alcibiades remains a concealed figure in the Republic. ${ }^{19}$

\section{The Paranomía of Alcibiades}

As we learn in reading Thucydides, Aristophanes, and Plutarch, the Athenians suspected, correctly or incorrectly, that Alcibiades was aspiring to tyranny. Seager has demonstrated that the main motif of these accusations was not the audacity and immoderation that he had demonstrated in the military and political arenas but rather the scandalous nature of his private life (of his epitedeúmata) and his paranomía. ${ }^{20}$ This is how Thucydides depicts Alcibiades militating in favour of the Sicilian expedition:

He was, you see, famous among the common people, and he indulged his passion for horse-racing and other extravagances far beyond his means. More than anything else, however, this relationship with the public is what later brought Athens to ruin, because most people came to fear the paranomía of

\footnotetext{
17) See Ober (2003). This paper contains many illustrations. For a clear exposition of Thucydides' critical attitude towards this origin myth, see Palmer (1982), 109-115 and on the real significance of the 'erotic' character of this origin myth, see the brilliant explanations of Forde (1989), 149.

18) See, among others, Raaflaub (2003), 62 sqq, especially the section "The ideologization of tyrannicide," McGlew (1993), 185 sqq, and De Romilly (1995), 103.

19) Insofar as the relation between Socrates and Alcibiades proved to be politically compromising. See Larivée (2005), 186. "Il pourrait bien être question d'Alcibiade là où il n'est pas nommé" writes Jacqueline de Romilly, who emphasizes how the case of Alcibiades haunted Plato and had "de près ou de loin, nourri sa réflexion" (1995), 246.

${ }^{20)}$ See Seager (1967) who examines the accounts of, among others, Thucydides, Xenophon, Isocrates, Lysias, and Andocides. "The charge was brought because of his epitedeùmata (...). Alcibiades was to be feared as a dangerously anti-social force in the life of Athens, not because of some suspected coup d'état. (...) If men believe that Alcibiades wants to be tyrant, it is because he acts as if he were tyrant already", 16. See also Davidson (1999), 298.
} 
his way of life (têes te katà tò heautoû sôma paranomías es tèn díaitan) and of the extremes to which his ambition took him in everything he did. ${ }^{21}$ They turned on him when they decided that what he really wanted was to become tyrant, and even though in his public capacity he was their best military strategist, they so resented his behavior in private life (tô̂s epitedeúmasin autoû) that they turned over the conduct of the war to other men and quickly brought down their city. (Peloponnesian War VI, 15)

Plutarch gives us a more precise idea of the nature of the paranomía manifest in Alcibiades' private life and explicitly links the accusation of aspirations to tyranny to his troubling erotic life:

But along with his statesmanship, eloquence, pride, and ingenuity went, by contrast, a luxurious lifestyle, (tèn truphèn tếs diaites), his over-indulgence in drink and sex (peri pótous kai érotas hubrismata), effeminacy of dress-he would trail his purple-dyed clothing through the city square-and incredible extravagance. [...] he had a shield made, with golden tracery, which bore, instead of an ancestral device, an image of Eros holding a thunderbolt. ${ }^{22}$ Faced with all these aspects of his behavior, the notable men of Athens combined feelings of abhorrence and disgust with fear of his haughty attitude and paranomía, which struck them as tyrannical in its excessiveness (ephoboûnto tèn oligorian autoû kaì paranomian hos turrannikà kaì allókota). (Life of Alcibiades, 16, 1-2)

Several questions arise here. To start, how do we explain this special attention paid to Alcibiades' behaviour in his private life? Let us begin by noting that in the Greek context, the squandering of personal resources to hedonistic ends is a motif of reprobation since the affluent citizens were supposed to finance various liturgies. As Davidson explains: "an inheritance dissipated in vices is not only lost to the individual and to his family, his heirs and rival claimants, it is also lost to the city. That banquet could have paid for a triereme. All the money wasted on hetareas could have gone on

21) Given that "he hoped that his success would bring him, personally, the benefits of wealth and prestige" (VI, 15, 2).

${ }^{22)}$ Mention of this shield can also be found in Athenaeus, 12.534e. Littman (1970), 267-8, suggests that this image is a comedic invention, but the context of the passage, in Plutarch at least, has nothing comedic about it. 
festivals to honour the gods instead." ${ }^{23}$ But in the case of a political figure, paranomic behaviour in private life is above all a source of concern insofar as it is considered a reflection of that figure's possible behaviour towards the polis: the debauched man "who had sold his own body in hybris would readily sell the common interest of the city as well," Aeschines declares in his Against Timarchus. ${ }^{24}$ This analogy is central in the Republic where the types of government are examined as magnifications of the types of human souls. If this intuition is correct, the way Alcibiades governs his own life is a good indicator of the way that he would govern the polis. Now, the way he leads his life is 'paranomic'.

I cannot present a detailed picture of Alcibiades' paranomía here; that would be a lengthy endeavour even if we were to limit ourselves to his love life, which consisted in a succession of debaucheries, adulteries (the most noteworthy of which is the seduction of the queen of Sparta), abuses against his lovers, behaviours and attitudes that point towards an ambivalent sexual identity, rumours of incest, etc. ${ }^{25}$ Alcibiades is also no stranger to violent acts that aim to belittle those he regards as inferiors. We find in him an explosive cocktail of sex, the "pleasure of shaming", and the "eroticization of hierarchy". ${ }^{26}$ Now, sensuality, splendour, extravagance, violence and transgression: these are the things that characterized the lifestyle of the tyrannos in the collective imagination. As Wohl writes: "it is impossible to segregate the tyrant's sexuality from his political power: each symbolizes the other. His notorious perversions (adultery, bigamy, rape, incest, sadism, necrophilia [...]) are the sexual manifestation of his extraordinary relation to the laws and norms of the polis. He exercises his rule in the form of sexual power. ${ }^{27}$ Given his life-style, it is therefore not surprising that Alcibiades was suspected of aspiring to tyranny, or that he was blamed for the scandal of the mutilated herms.

How does one translate the term paranomía? Ludwig suggests "contrariness to the law" ${ }^{28}$ but what is aimed at here is even better rendered by Wohl

\footnotetext{
23) Davidson (1999), 245. See, for example, Aeschines, Against Timarchos, 97.

24) Against Timarchos, 29.

25) See the chapter "Insolences et scandales" in Romilly (1995). For a daring analysis of the sources, see Wohl (2002), 130-144; for a cautious analysis of the sources, Littman (1970).

26) Ludwig (2002), 189, 191.

27) Wohl (2002), 221.

28) Ludwig (2007), 229.
} 
who speaks of "abnormality, transgression, illegality, perversion" ${ }^{29}$ Thucydides and Plutarch's insistence on Alcibiades' paranomia suggests that in effect the fear caused by his life-style was not simply linked to the risks of being ruled by a leader possessed by onerous and excessive desires who cared little for the laws. It is true, as Forde emphasizes, that it was believed that Alcibiades aspired to tyranny because the luxury of his life-style suggested that he was already living like a tyrant. Indeed, Forde remarks that Alcibiades' Olympic chariot victory had been interpreted in that way: "Entering a large number of chariots at the Olympic games, it should be noted, was a hallmark of tyrants, whose wealth, by reason of their despotism, was essentially no less than the wealth of their cities. ${ }^{{ }^{30}}$ It was his sexual conduct, however, that caused much graver distress and fear of the possible subversion of the normative order and the foundations of the polis itself. "Translegal desires", Benardete writes, "are desires that violate the fundamental requirements of the city and acknowledge fully the fictions of the city".$^{31}$ And indeed, the paranomic desires that Plato calls to mind in book IX are troubling in that they transgress and subvert the foundations of the polis..$^{2}$

In any event, the texts cited above suffice to prove that Plato did not invent anything in placing eros and paranomic desires at the heart of his description of the tyrannical man's genesis. Plato did not have the accomplished tyrant Dionysus the $1^{\text {st }}$ in mind but rather a potential tyrant, like

29) Wohl (2002), 126. On paranomía, see Wohl (2002), 129-144, Larivée (2005), 177-80. The following translations do not seem strong enough: Parry (2007), 395: "outlaw appetites"; Scott (2007), 139: "lawless desires"; Chambry, Robin, Leroux: "désirs déréglés". These translations overlook the transgressive and monstrous aspect of the desires we are concerned with here. The paránomoi ópseis of $572 \mathrm{~b} 1$ designate overtly perverse, monstrous visions.

30) Forde (1989), 78.

31) Benardete (1989), 205. Scott (2007), 139, echoes this: "lawless desires are inherently destructive of society and of the relations that should exist between human beings (...) lawless desires involve the transgression of boundaries that would tend to destroy the very possibility of human relationships, family, and society, not just destabilise them".

${ }^{32)}$ Schmitt-Pantel (1979), analyzes the passage from Herodotus where he mentions the order given by the tyrant Periander to send three hundred sons from the citizens of Corcyra to Lydia to make them eunuchs. This example reveals, to her eyes, how the tyrant, far from just ignoring civic norms, aims at subverting them. See Wohl (2002), 22-24 for an interpretation of how this spirit of subversion is manifest in the mutilation of the herms, a hostile gesture by a would-be tyrant (Alcibiades) against the democratic ideal of isonomy. 
Alcibiades. The figure of Alcibiades demonstrates that the two aspects that Annas attempts to isolate-the paranomic fury of desire and political savvy_are in fact reconcilable. Extremely intelligent and ambitious in political matters, a powerful orator, an able strategist and keen soldier, he was equally excessive and exuberant in his private life, a great lover of feasts and binges, sexually insatiable and prone to transgressions of all sorts, violent and arrogant towards those nearest to him. Furthermore, Annas forgets that in the democratic context discussed at the end of book VIII, the "fact of having power over others" is an affair of seduction and that seduction is necessarily linked to eros. The democrat on the road to tyranny, like Alcibiades, is essentially erotic: not only is he violently animated by eros but he also knows how to arouse it in others.

\section{Political Eros and the Figure of the Dêmerastés}

The figure of Alcibiades will allow us to better define the nature of this eros called to play the role of prostates of the soul in the face of other desires in Republic IX. We have said that it is not impossible that this éros túrannos designates a romantic obsession and an addiction to sensual pleasures. Given that, in the minds of the Athenians, there was a close link between tyranny and the violent satisfaction of erotic impulses, this interpretation seems plausible. However, the case of Alcibiades reveals that romantic passions-paranomic or not-do not exhaust the sense of eros that ensnares the soul of the potential tyrant. Indeed, these passions are perhaps nothing more than the satellites of a more powerful kind of eros. We bear in mind here that immense political ambition which resulted in an intense erotic relationship, full of twists and turns, between Alcibiades and the Athenian dếmos..$^{33}$ Thus Socrates explains, in the Alcibiades I, that the hope $^{34}$ that spurred Alcibiades on was not limited to being given greater honour than Pericles among the Greeks, but that the young man "would rather not live" if he could not also shine in Asia and have his "reputation and [his] influence saturate all mankind" (Alc., 105c). This is what Alcibiades longs for "more than anyone else ever longed for (erân) anything", Socrates asserts $\left(124 \mathrm{~b}_{5}\right)$. The eros that moves Alcibiades corresponds to a

\footnotetext{
33) On the topic of ambition, see De Romilly (1995), 257.

34) On the relationship of eros and elpis, see Cornford (1965), 206.
} 
great ambition that is rooted in an extreme form of narcissism and a boundless appetite for glory and conquest. ${ }^{35}$ And, as several texts confirm, this formidable eros initially took the form of an intense love of the dếmos. In the Alcibiades I, it is precisely this love that worries Socrates (who explicitly mentions the attraction that tyranny holds for Alcibiades and the city in $135 \mathrm{a}-\mathrm{b}$ ) and that he considers his only real rival for the young man: "I shall never forsake you now, never, unless the Athenian people make you corrupt and ugly. And that is my greatest fear, that a love of the common people might corrupt you. ${ }^{36}$

This erotic way of conceiving the dynamic between the ruler and the ruled-as in a pederastic relationship - is not Plato's invention. We find the same erotic vocabulary in Aristophanes and Thucydides. For example, think of the famous funeral oration in which Pericles exhorts the people to act as genuine "erastes" of the city, or of the discourse in which Nicias attempts to dissuade the Athenians from undertaking the Sicilian expedition, by asking them to not give in to a "fatal passion" (dusérotas eînai) for something beyond their grasp. ${ }^{37}$ Far from being a bygone metaphor, the use of this kind of sexual vocabulary inspired by pederasty was emblematic of a very particular dynamic in Athenian political life..$^{8}$ The potential leader who presents himself before the assembly to give his counsel is enamoured of the dêmos and he hopes that it will favour him by allowing him to guide

35) For a discussion of the possibility for a tyrant satisfying such a political ambition by purging himself of eros in the sense of romantic passion, following Xenophon in the Cyropedia, see Newell (1983), 901-905.

${ }^{36)}$ Alc. 132a (see also 135e). Socrates gave a similar reply to Callicles in the Gorgias: "I realize that you and I are both now actually sharing a common experience: each of the two of us is a lover of two objects, I of Alcibiades, Clinias' son, and of philosophy and you of the demos of Athens, and the Demos who's the son of Pyrilampes" (Gorg, 481d), an image that Aristophanes already exploited to ridicule Cleon in The Knights, 732: "Hotiè philố s', $\underline{\hat{o}}$ Dê̂m' erastés t'eimi sós".

37) Peloponnesian War, II, 43, 1; VI, 13, 11. For Nicias' quote, see Cornford (1965), 203, for that of Pericles, see Monoson (1994), Forde (1989), 30 sqq, and the section "Lovers of the City: Tyranny and Democracy in Classical Athens" in McGlew (1993), 188.

${ }^{38)}$ The sexual connotation of this metaphor is indeed manifest, as is evident in the passage from the Alcibiades I where Socrates warns the young man: "The great-hearted people of Erechtheus' might look attractive on the outside, but you need to scrutinize them in their nakedness, so take the precaution I urge" (Alc., 132a). Ludwig (2002), 147, explains that the meaning of eros evoked here cannot be generic since the sense of the words erastes (contrary to eros) was narrow. It referred specifically to pederastic relations. 
it in the same way that an erastes guides his eromenos. But to accomplish this he must first carry out a compelling seduction. Clearly, seduction always plays a crucial role in politics-particularly in democracy-but in this regard the case of Alcibiades seems to be peculiar. In spite of all of his overindulgence and his extravagance, his charm and his power to seduce (which Plutarch constantly returns to) ${ }^{39}$ were such that the people allowed him everything. Aristophanes' description of the dêmos' disposition towards Alcibiades is eloquent: "They miss him, hate him, want him to be with them. ${ }^{{ }^{40}}$ Furthermore, it is plausible that the Athenians' suspicion of what they interpreted as Alcibiades' aspiration to tyranny actually originated from the intensity of their own passion for him. Indeed, the ambivalent passion that the people held for this enfant terrible was such that one could reasonably fear that the demos might voluntarily enslave itself to eros tyrannos. This is, in any case, what the following noteworthy episode suggests: after his triumphant return from exile, in 407 , Alcibiades "became so popular with the lower, poorer classes that they conceived a passionate longing for him to rule over them as tyrant (hôst'erân éróta thaumastòn hup'ekeínou turanneîsthai)"!!1 These accounts help us in identifying these tyrannopoioi that Socrates blames for the implanting of a tyrannical eros in the soul of the young democratic man, which I return to now.

\section{The Identity of the Tyrannopoioi}

Apart from the portrait of tyrannical eros, there is yet another passage in the Republic that is clearly inspired by the figure of Alcibiades: the passage in book VI on the corruption of the philosophic nature. What is unusual about this nature, Socrates explains, is that its own qualities - ethical, intellectual, physical qualities and also those linked to birth—paradoxically

\footnotetext{
39) See for example:Alcibiades, 24, 5: "No one, whatever his character or temperament, could fail to be touched and captivated by Alcibiades' charisma, if he spent time and lived with him on a daily basis; even those who feared and envied him found themselves enjoying his company and warming to him once they were with him and could actually see him."

40) The Frogs, v.1425, cited by Plutarch, Alcibiades, 16, 3 .

41) Plutarch, Alcibiades, 34, 7. According to Forde, Alcibiades' talent for seducing and persuading (his "persuasive passion" and his passion for persuasion) indicated that Alcibiades was not seeking a tyranny: "What Alcibiades craves is voluntary and conscious recognition of his superiority, not tyrannical imposition of his will," Forde (1989), 93, 186.
} 
"tend to corrupt the soul that has [them] and drag it away from philosophy" (491b-c). Why? Because those who surround the young man attempt to use these qualities to accomplish their own designs in the sphere of politics:

So as he gets older, I imagine his family and fellow citizens will want to make use of him in connection with their own affairs. (...) They will get down on their knees, begging favors from him and honoring him, flattering ahead of time the power that is going to be his, so as to secure it for themselves. (...) What do you think someone like that will do in such circumstancesespecially if he happens to be from a great city where he is rich and noble, and if he is good-looking and tall as well? Won't he be filled with an impractical expectation and think himself capable of managing the affairs, not only of the Greeks, but of the barbarians too? And won't he exalt himself to great heights, as a result, and be brimming with pretension and empty, senseless pride? (494b-d)

The parallels with the Alcibiades I are striking. ${ }^{22}$ And in light of this passage, the question of the identity and intentions of these "tyrant-makers" mentioned in $57225^{-} 6$ becomes all the more clear. Those who are at the origin of this tyrannical eros, who foster above all an appetite for conquest and an immoderate ambition are some of the young man's relatives and fellow citizens who will do anything to exploit his talents in the arena of politics finally transforming him into a lover of the people rather than an "erastes of the truth". ${ }^{43}$ But how is this sort of immoderate political ambition linked to the paranomic eros for sensual pleasures, described in book IX?

\section{The Link between Eros as an Addiction to Sensual Pleasures and as Political Ambition (Alcibiades I and Symposium)}

Once again, the figure of Alcibiades allows us to catch a glimpse of the solution - or rather two possible solutions. To start, we might think, along with Davidson, that there is a progression and causal link between the obsession with sensual pleasures and tyranny as political domination. Alcibiades, he argues, is in fact the paradigmatic figure that "crystallized

42) See Alc. I, 103a-106a.

43) Rep. 492b-d. For the expression "aletheía erastaí" see $501 \mathrm{~d} 2$. 
[the] metaphorical sequence from banqueting to tyrannizing". ${ }^{44}$ According to his understanding of the character of Alcibiades, the immoderate sensual appetites come first while the political ambition arises as a means to obtain the necessary resources to satisfy this obsession with pleasure. In the case of Alcibiades, Davidson explains:

It was not just that a man of 'tyrannical lifestyle' seemed to covet the kingsized pleasures reputedly enjoyed by the monarchs and satraps of Persia and the Greek dictators of long ago. Rather, a tyrannical man's desires were already outpacing the resources of a private citizen and forcing him into extremity. He needed to overthrow the system to get himself out of debt. It was not so much a tyranny of aspiration as a tyranny of desperation. ${ }^{45}$

According to the social imaginary of the epoch that viewed "crime as the result of straitened circumstances", paranomia would simply be a consequence of immoderation in the pursuit of pleasure ${ }^{46}$ But this is not the only possible interpretation. On the contrary, we might think, in keeping with Forde (whose interpretation rests on the explanations offered by Alcibiades himself in Thucydides) that the splendour of a flamboyant lifestyle is actually a method of realizing an immense political ambition. Thus, according to Forde: "All of Alcibiades' excess is dedicated to his project of political rule (...) The only way Alcibiades as one man can hope to bring his project to fulfillment is by becoming in every way bigger than life. This he does in part through an opulence that for any ordinary, 'private' individual would be the height of unjustified, even boastful, self-indulgence." ${ }^{77}$ The spectacular character of Alcibiades' Olympic victories, for example, and the splendour with which he surrounded himself on this occasion can be seen as a source of prestige, as the means to rouse admiration and therefore to acquire political power.

44) Davidson (1997), 293: "The essential problem was that he was subsidized by the cities of Athens' empire, the Ephesians supplying a Persian tent, the Chians providing provender for his horses, the Cyzicenes victims for the sacrifice and the Lesbians the wine and all his other daily needs. The similarities with the 'King's Dinner' and Themistocles' Persian prerogatives must have been obvious to everyone".

45) Davidson (1997), 299.

46) Davidson (1997), 247.

47) Forde (1989), 202. 
To which of these two explications does Plato subscribe? One way to answer this question and to better understand the genesis of the tyrannical character is to examine the evolution from the young, pre-tyrannical Alcibiades described by Plato in Alcibiades I to the flamboyant Alcibiades at the end of the Symposium, when the transformation is well underway.

In the Alcibiades I, Plato presents Alcibiades at a critical moment, when he is preparing to make his entrance into the political arena. Although still young, Alcibiades is already animated by a "gargantuan" political ambition, as Angela Hobbs notes. ${ }^{48}$ Socrates, who presents himself as Alcibiades' erastes, guesses that his eromenos' desire for honour will carry him beyond the limits of the city, of Greece, of Europe, and even Asia... The eros that animates Alcibiades is neither sensual nor paranomic; following Hobbs' vocabulary, Alcibiades is depicted here as possessing an essentially thumoeidetic temperament. It is indeed honour and political conquest that have seized the young Alcibiades at this moment in his life. Socrates alone created the erotic (in the current sense) atmosphere of the exchange and not Alcibiades, who remained relatively passive and receptive in Socrates' romantic speeches and philosophical remarks. ${ }^{49}$ Guided by Socrates, Alcibiades willingly recognizes his own ignorance in matters important to leadership and he acknowledges his lack of concern for epimeleia heautou (self-care). Thus he accepts without hesitation Socrates' main conclusion, which invites Alcibiades to take care of himself and to devote himself to learning before devoting himself to the affaires of the city. That being said, in spite of Alcibiades' fine philosophic and amorous disposition, Socrates' concern for the corruption of his beloved is palpable. Not only does Socrates express his fear that Alcibiades will be corrupted by the love of the demos but at the end of the dialogue he explicitly cautions him against the temptation of tyranny, both for himself and for the city. ${ }^{50}$ Although Socrates is

48) "His ambition for victory, power and honour is, quite simply, depicted as gargantuan (104e-105e)", Hobbs (2000), 254.

49) Socrates strongly insists, in the middle of and at the end of the dialogue, on his love for Alcibiades and on the duties that he considers proper towards his beloved. See 103a-104e, 135c-135e, as well as 131c-d. Regarding Alcibiades' loves, all that we know is that he has scorned and conquered all his lovers. See 104c.

${ }^{50)}$ Here are the relevant passages, 132a: "I shall never forsake you now, never, unless the Athenian people make you corrupt and ugly. And that is my greatest fear, that a love of the common people might corrupt you, for many Athenian gentlemen have suffered that 
deeply concerned by the risk of Alcibiades becoming corrupted-that is, developing a tyrannical soul and becoming a terrifying political tyrantthere seems to be a possibility of preserving the qualities of this philosophic nature and correctly orienting his eros.

In the Symposium Plato offers us a short but brilliant account of Alcibiades' mature life. Here again we see Alcibiades at a pivotal moment in his evolution; the scene is set just before he is faced with the scandal of the mutilation of the herms and the disastrous Sicilian expedition. The contrast between the portrait of the Alcibiades I and that of the Symposium is striking. Alcibiades drunkenly bursting into the banquet with his drinking companions - where up until then the guests had been engaged in a calm and sober discussion on the nature of Eros - suggests that something like a fall from thumos to epithumia has taken place in his soul. More precisely, we may guess that there has been a regime change, from the violence of thumos, hungry for honour and conquest, to the pleasure-seeking epithumetikon. The following scene illustrates this well: after proclaiming himself the banquet-leader in an authoritarian tone, Alcibiades, catching sight of a cooling jar, orders a slave to fill it with wine and proceeds to consume its entire contents (two and a quarter litres!)..51 Alcibiades' excessive and tumultuous behaviour recalls the description of the genesis of the young tyrant in book IX of the Republic. As Hobbs describes it,

... The text makes it plain that, at thirty-four, Alcibiades is not simply governed by his thumos as opposed to his reason: he is also clearly depicted as being in the grip of all his non-rational elements; in the term of Republic 8, he is a disturbing example of a timocrat sinking into the chaotic existence of the democratic anarchist. His crown of ivy and violets links him to Dionysus and Aphrodite, the divinities of wine, sex and general epithumeitic disorder, and a

\footnotetext{
fate already"; 135e: "I should like to believe that you will persevere, but I am afraid—not because I distrust your nature, but because I know how powerful the city is-I'm afraid it might get the better of both me and you"; 134e: "Because my dear Alcibiades, when an individual or a city with no intelligence is at liberty to do what he or it wants, what do you think the likely result will be? For example, if he's sick and has the power to do whatever he likes-without any medical insight but with such a dictator's power (turannoûnti) that nobody criticizes him —what's going to happen? Isn't it likely his health will be ruined?"; 135b: "Well then, my good Alcibiades, if you are to prosper, it isn't supreme power (turannida) you need to get for yourself or the city, but virtue".

51) $213 \mathrm{e}-214 \mathrm{a}$.
} 
fragment of Pindar suggests that the violets also symbolize democratic Athens. Another telling detail is the fact that he enters supported by a flute girl: much earlier in the proceeding the other symposiasts pointedly dismissed a flute girl on the grounds that flute music distracted from serious discussion (176c). [...] flute music is also condemned for encouraging loss of control at Republic 399d-e, while at 561c intermittent bouts of 'getting drunk to the sound of the flute' are said to be a marked feature of the indulgent democratic character. At Alcibiades I 106e, too, the youthful and thumoeidic Alcibiades is said to have refused to learn the instrument; yet, by thirty-four, it would seem, the undisciplined democratic rot has set in..$^{2}$

The epithumeitic component is equally evident in Alcibiades' account of his (failed) attempt at seducing Socrates. Far from playing the traditional role of the eromenos who tries to resist the sexual advances of an erastes, Alcibiades presents himself rather as an active eromenos, determined to employ every possible strategy to convince his erastes to appease his sexual desires. Given that Socrates showed himself to only be disposed to Alcibiades' moral education without demanding any sexual favours and further that he does not accord physical beauty much importance, ${ }^{53}$ the explication for Alcibiades' eagerness to offer himself sexually seems to be his own sexual desires. It would be an error, however, to only see an epithumeitic nature in his eagerness for seduction. His sexual advances are linked to a desire for conquest in love, a desire for power, for indeed they are inseparable. ${ }^{54}$ To achieve his ends, Alcibiades does not hesitate to subvert the traditional roles of the erastes and the eromenos: the power dynamic is reversed and the social norms transgressed..$^{55}$ Furthermore, Socrates from the start emphasizes the tyrannical traits of Alcibiades' eros for him when he describes Alcibiades as an overly jealous and violent lover, in the grip of madness (mania)...

'Be ready to protect me, Agathon', said Socrates, 'for I find that the love (éros) of this fellow has become no small burden. From the moment when I first fell in love with him I haven't been able to exchange a glance or a word with a

52) Hobbs (2000), 256.

53) Cf. Alc. 131c-d.

54) Alcibiades says he was humiliated by Socrates' rejection of his advances, 219c-e.

55) Alcibiades' desire for subverting the roles was already evoked at the end of the Alcibiades I, see $135 \mathrm{~d}$. 
single good looking person without his falling into a passion of jealousy and envy, which makes him behave outrageously and abuse me and practically lay violent hands on me. See to it that he doesn't commit some excess even here, or if he attempts to do anything violent, protect me; I am really quite scared by his mad behaviour and the intensity of his affection (tèn toútou manían te kaì philerastían $) \cdot{ }^{6}$

These remarks are clearly made partially in jest, but nevertheless they subtly reveal Alcibiades' hybristic tendencies; Alcibiades who, moreover, openly confessed that he sometimes wished for Socrates' death. ${ }^{57}$

But let us return to the initial question. What do we learn from the juxtaposition of these two portraits of Alcibiades with regards to the genesis of the tyrant? Is Plato of the opinion that the proliferation of the epithumeitic desires in private life leads to political tyranny (understood here instrumentally, as a means for procuring resources) as Davidson thinks? Or does he think rather that a flamboyant personal life, full of excessive pleasures, is only an instrument that enables one to satisfy an extraordinary political ambition, as Forde suggests? Between the two moments described by Plato, we do not know precisely what occurred in Alcibiades' life. We do know, however, that in the Alcibiades I the desire for honour, political ambition, and thumoeidetic traits are predominant and reach 'erotic' levels. Despite his good nature, Socrates fears that the love of the demos will corrupt Alcibiades and finally lead him into tyranny. The Symposium shows us a completely changed Alcibiades. What Socrates feared has indeed come to pass: Alcibiades admits that he has succumbed to his desire to be honoured by the crowd $\left(216 b_{5}\right)$. He is now dominated by an inordinate epithumeitic leaning; his epithumia has subordinated his thumoeidetic traits and this gives rise to an erotic relation to others that is tyrannical in its intensity (his relation to Socrates, for example). Alcibiades' metamorphosis between the two dialogues leads one to think that, according to Plato, the genesis of the political tyrant occurs when a thumos, ignited by eros (intense desire for honour and political conquest) is somehow contaminated by epithumia (a desire symbolized and nourished by the demos). Thumos then likely becomes the means of finding the necessary resources to satisfy those erotic desires which know neither limits nor norms. To put it differently,

\footnotetext{
56) Symp. 213-c-d, trans. Hamilton.

57) Symp. 216c.
} 
the relation described by Davidson follows the one described by Forde. They do not exclude but complement one another.

What to think, then, of the comparison that Davidson makes between the genesis of the tyrant in Rep. IX and Aeschines' Against Timarchus? Davidson suggests that "the star of Plato's tale of the tyrannical man is the same as the star of Aeschine's biography of Timarchus, desire"..$^{8}$ The parallels that Davidson draws with the genesis of the tyrant in the Republic are indeed illuminating in that Aeschines insists on the link between Timarchus' insatiable sensual and sexual desires, the dissipation of his inheritance and his paranomic lifestyle. Nevertheless, there remains a notable difference between the developing tyrant of Rep. IX and Timarchus-specifically, eros. Timarchus recklessly spent his resources because of a lack of selfcontrol and he may have prostituted himself but he was not at risk of becoming a tyrant. For such a transformation to take place, the presence of a certain eros in the soul is necessary. Furthermore, thinking of the tyrant's genesis through a model $\grave{a}$ la Timarchus ${ }^{59}$ rather than through the model offered by Alcibiades does not allow us to understand the crucial link between the tyrant and the philosopher, which I turn to now.

\section{Conclusion: The Philosopher and the Tyrant as 'Erotic Men'}

In closing, let us return to the passage concerning the corruption of the philosophical nature. This passage presents yet another point of interest for the interpretation of the tyrant's genesis at the beginning of book IX

\footnotetext{
${ }^{58)}$ Davidson (1997), 301. "Aeschine's image of pleasure-seekers as murderers, law-breakers, pirates and plunderers, linking the pleasures of the flesh to savagery and barbarism, shares a great deal with Plato's desire-driven profligates who haunt the streets at night, snatching cloaks, breaking into houses, cutting purses and end up wandering the world in mercenary armies". See Against Timarchus, 42, where Aeschines explains that Timarchus was led to prostituting himself because of his addiction to sensual pleasures, which then led to him squandering away his inheritance.

59) I would like to emphasize here that I do not pretend that Timarchus could have served as the model for depicting the genesis of the tyrant in the Republic, which is impossible from a chronological point of view in that the Against Timarchus by Aeschines was composed later. I simply suggest that the contemporary reader of the Republic would be mistaken in understanding the description of the tyrannical soul in Republic $I X$ in light of the description of Timarchus that Aeschines offers in his Against Timarchus (as much as it is tempting), insofar as it is missing a crucial element: eros.
} 
insofar as Plato suggests, albeit discretely, that the tyrant and the philosopher are closely related. Socrates indeed declares that the worst evils are not committed by mediocre natures, but in fact by the most gifted ones. The most gifted souls will be led away from philosophy by their own talents if they are not brought up well and they will become exceptionally bad; as Socrates explains: "men who possess it [a philosophic nature] are the ones that do the worst things to cities and individuals" (495a-b). Now, the worst evils-and this is what Socrates has tried to show throughout the Republic - are the fruit of the tyrant... This troubling kinship between the philosopher and the tyrant- two erotikoi androi ${ }^{60}$ two obsessive individuals in whom desire flows, concentrated, in a single direction ${ }^{61}$ - has been called to mind by many interpreters and has recently been given a detailed investigation by G. A. Scott. ${ }^{62}$ In an earlier study I concluded, along with these interpreters, that the philosopher and the tyrant are two possible avatars of a single nature, the philosophic nature, moving towards the good or evil according to the orientation of its eros. ${ }^{6_{3}}$ This interpretation now appears to be partially lacking. It must indeed be corrected, or clarified at least, in light of certain remarks by Rosen who, in his commentary on the Republic, poses the following question: "Are we to suppose that if

\footnotetext{
6o) Socrates describes Glaucon as an andros erotikos in $474 \mathrm{~d} 3$. Besides the fact that both are 'erotic' and obsessed, the philosopher and the tyrant have a problematic relationship with society. Scott (2007), $151-52$, holds that the philosopher is "asocial" and that the tyrant is "anti-social", while Ludwig (2007), 230, describes the philosophers as "anomian" and the tyrant as "antinomian". This distinction, which does not seem to me entirely satisfactory, would demand a whole study in itself.

${ }^{61)}$ “... when someone's appetites are strongly inclined in one direction, we surely know that they become more weakly inclined in the others, just like a stream that has been partly diverted into another channel" (485d). See A. Cacoullos (1973), 91 n.15: "This is how Plato characterizes erotic motivation, namely, as a channelling of energies or resources. One who is motivated by eros does not exhibit dissipation and fragmentation," and especially Dixsaut (2001) "Dire oui à Erôs, c'est toujours à nouveau dire non à tout le reste", 138.

${ }^{62}$ Scott (2007). Ludwig (2007), 230, asserts that the philosopher is the "erotic counterpart" to the tyrant; according to O'Connor (2007), 66, "the potential philosopher is also the potential tyrant"; Chanteur (1980), 170, asks for her part: "Le tyran ne serait-il qu'un philosophe qui n'a pas reçu l'éducation qui lui convient?"; and Giorgini (2009), 144, speaks of their "shared original nature", asserting that "the tyrant is a potential philosopher led astray".

${ }^{63}$ L Larivée (2005), 193-197. See also Dorter (2006), 268; Dixsaut (2001), 264. Giorgini (2009), 121-25, insists on the possibility of a "re-education" of a tyrant by a "re-orientation of eros". This thesis seems very optimistic to me.
} 
Alcibiades had been raised by Socrates instead of Pericles, he would have become a philosopher rather than seeking to conquer Greece? Conversely, suppose that Socrates had been raised by Pericles. Are we to believe that he would have become like Alcibiades?"64 To answer these questions, certain distinctions are necessary and we must return to the way that eros is "implanted" in the soul by the tyrant-makers.

It is true for many philosophers that tyranny represents-as Nietzsche suggested of Plato and Socrates - a temptation and a spectacular form of possible corruption, whether the philosopher seeks to wield real political power or displays a "dogmatic arrogance" by attempting to "impose its views on the human race" as Rosen explains. ${ }^{6}$ Thus, many commentators have emphasized the ambivalent erotic character of Glaucon, Socrates' primary interlocutor in the Republic, who seems well disposed towards philosophy but equally fascinated with tyranny (which once again recalls Alcibiades). ${ }^{66}$ If, however, the philosophic nature can be corrupted and become tyrannical in certain individuals, that does not mean that all tyrants are, in reality, corrupted philosophic natures. ${ }^{67}$ Is it plausible to think, Rosen asks, that "Alexander, Napoleon, Hitler, and Stalin would have become genuine philosophers had they received the proper education"? ${ }^{68}$ Rosen's objection seems convincing: while the thirst for knowledge can become the thirst for power (or express a thirst for power), the thirst for power in a tyrant does not necessarily indicate the presence of thirst for knowledge that was not properly nurtured. In fact, in his explications of the origin of the tyrant, Socrates clearly indicates that there are tyrannical tendencies (or at least paranomic desires) in all of us $(571 \mathrm{~b}-\mathrm{d})$, which is certainly not the case for philosophic tendencies which are present in only a select few. ${ }^{69}$ There are therefore 'ordinary' tyrants, so to speak. That said, we

\footnotetext{
64) Rosen (2005), 236.

$\left.{ }_{65}\right)$ Rosen (2005), 238. Concerning the "passion du pouvoir", "violence" and "pulsion d'emprise" of the philosopher, see Delacampagne (2000), 178 .

66) O'Connor (2007), 65-67; Ludwig (2007), 225. Glaucon's ambivalence indicates the protreptic character of the Republic, Larivée (2005), 194-95.

67) Brisson points out in a recent article that the turannos kosmios of the Laws possesses similar characteristics to the guardians of the Republic, Brisson (2009), 134. If we can imagine a philosophic nature becoming such a turannos kosmios, it is difficult to imagine, conversely, that the tyrannical soul of Rep. IX could become a philosopher.

68) Rosen (2005), 238.

69) The philosophic nature "is seldom found among human beings, and there will be few who possess it” Rep. VI, 491b, 495b.
} 
can suppose that the (tyrannical) corruption proper to the philosophic nature is a particularly engrossing topic for Socrates not only because the philosophic nature can achieve greater evil (given its superior talents) but because a corrupted philosophic nature is lost equally to philosophy as to the city that it could have virtuously governed.

But let us return to the doubt that Rosen expresses when he asks: "Are we to suppose that if Alcibiades had been raised by Socrates instead of Pericles, he would have become a philosopher rather than seeking to conquer Greece? Conversely, suppose that Socrates had been raised by Pericles. Are we to believe that he would have become like Alcibiades?" First we have to understand that in the Alcibiades I, the Symposium, as well as the passage from the Republic concerning the corruption of the philosophic nature, it is the influence of something like a social environment that is targeted, and not the influence of a particular educator. ${ }^{70}$ What Socrates fears when he attempts to convert the young Alcibiades to philosophy is the deleterious influence of the demos. ${ }^{71}$ And later, in the final scene of the Symposium, Alcibiades himself attributes his negligence of Socrates' teachings and of philosophy to the desire for honours accorded by the masses (Symp. 216a). The influence of the demos is also the main corrupting element that Socrates denounces in book VI of the Republic. ${ }^{72}$ In other words, the teaching of one lone individual when faced with the influence of a whole social and political environment is, except in rare cases, insufficient to protect an intensely erotic nature such as Alcibiades. ${ }^{3}$ That Alcibiades possessed, according to Plato, a philosophic nature is confirmed by the attention that Socrates paid him in the Alcibiades I, and that he was amenable to philosophy is clearly shown in the Symposium when Alcibiades himself describes the effect that his philosophical discussions with Socrates had on him:

Something much more painful than a snake has bitten me in my most sensitive part-I mean my heart, or my soul, or whatever you want to call it, which has been struck and bitten by philosophy, whose grip on young and eager souls is much more vicious than a viper's and makes them do the most amazing things. Now, all you people here, Phaedrus, Agathon, Eryximachus,

\footnotetext{
${ }^{70)}$ It is a question of a seed finding right nourishment, season and placement, Rep. VI, 491d.

71) See note 62, above.

${ }^{72)}$ Rep. VI, 492a-d.

73) On the exceptions to the rule, see Rep. VI, 496a-c.
} 
Pausanias, Aristodemus, Aristophanes-I need not mention Socrates himself - and all the rest, have all shared in the madness, the Bacchic frenzy of philosophy... (Symp. 218a-b)

According to the portrait offered by Alcibiades, Socrates, like a siren or satyr who enchants with the music of his flute (216c), puts his listeners into a possessed state $(215 \mathrm{c}-\mathrm{d})$. Certain traits of this text (the idea of possession, madness, the image of the bite) are strangely reminiscent of the passage on the role of eros in the genesis of the tyrant. We can conclude that the philosophic nature has an erotic predisposition but that the transition into mania (philosophic or tyrannical) requires the intervention of a powerful external influence which acts as a catalyst by providing eros with its object. Eros, properly speaking, does not come from the outside, but is ignited by an external intervention which, in a certain sense, provides its 'fuel' and gives it direction. The fact that Alcibiades did not become a philosopher is not explained by the absence of a philosophic nature or eros. Rather, whereas the demos quasi-constantly exerted its influence on him, Alcibiades needed only to withdraw from the company of Socrates to avoid having his eros fed and directed by philosophy. ${ }^{74}$ The lesson is clear: the influence of one sole teacher does not suffice to protect a highly gifted soul from tyrannical temptation; living-conditions—social, political—play a crucial role.

These final remarks confirm the hermeneutic fertility of the figure of Alcibiades for the interpretation of the passage on the tyrant's genesis. As I hope to have demonstrated, in the light of ancient accounts of Alcibiades' erotic nature and paranomía, the puzzling link that Plato established between eros and tyranny in book IX of the Republic becomes entirely intelligible.

\section{Bibliography}

Aeschines. 2001. Against Timarchos, Introduction, Translation, and Commentary by N. Fisher, Oxford: Oxford University Press.

Annas, J. 1981. An Introduction to Plato's Republic, Oxford: Clarendon Press.

Aristophanes. 2005. The Complete Plays, Translation by P. Roche, New American Library.

74) Symp. 216a-b. 
Benardete, S. 1989. Socrates' Second Sailing, Chicago and London: University of Chicago Press.

Boesche, R. 1996. Theories of Tyranny from Plato to Arendt, Univ. Park, Pennsylvania: The Pennsylvania State University Press.

Brisson, L. 2009. "Le tyran dans les Lois: la violence fondatrice. Une lecture de Leg. IV, 709d-712a", Le Philosophe, le roi, le tyran. Études sur les figures royales et tyranniques dans la pensée politique grecque et sa postérité, S. Gastaldi, J.-F. Pradeau (eds), Sankt Augustin: Academia Verlag, 129-137.

Chanteur, J. 1980. Platon, le Désir et la Cité, Paris: Sirey.

Cornford, F. M. 1965. Thucydides Mythistoricus. London: Routledge and Kegan Paul [1907].

Côté, C.-E. 1997. "The Significance of eros in Thucydides' Portrayal of Athenian Imperialism," Mémoire de Maîtrise en études classiques, Université d'Ottawa.

Davidson, J. N. 1997. Courtesans and Fishcakes: the Consuming Passion of Classical Athens, New York: St. Martin's Press.

Delacampagne, C. 2000. Le Philosophe et le tyran: Histoire d'une illusion, Paris: Presses Universitaires de France.

Dixsaut, M. 2001. Le Naturel Philosophe: Essai sur les Dialogues de Platon, Paris: Les Belles Lettres [1985].

Dorter, K. 2006. The Transformation of Plato's Republic, Toronto: Lexington Books.

Forde, S. 1989. The Ambition to Rule: Alcibiades and the Politics of Imperialism in Thucydides, Ithaca: Cornell University Press.

Giorgini, G. 2009. "Plato and the Ailing Soul of the Tyrant," Le Philosophe, le roi, le tyran. Études sur les figures royales et tyranniques dans la pensée politique grecque et sa postérité, S. Gastaldi, J.-F. Pradeau (eds), Sankt Augustin: Academia Verlag, 112-127.

Hobbs, A. 200o. Plato and the Hero. Courage, Manliness and the Impersonal Good, Cambridge: Cambridge University Press.

Larivée, A. 2005. "Malaise dans la cité: éros et tyrannie au livre IX de la République," Études sur la République 1. De la Justice, M.Dixsaut, A. Larivée (eds), Paris: Vrin.

Littman, R. J. 1970. "The Loves of Alcibiades," Transactions and Proceedings of the American Philological Association, Vol. 101, 263-276.

Ludwig, P. W. 2002. Eros and Polis. Desire and Community in Greek Political Theory, Cambridge: Cambridge University Press.

—. 2007. Eros in the Republic, in The Cambridge Companion to Plato's Republic, ed. G. R. F. Ferrari, Cambridge: Cambridge University Press.

McGlew, J. F. 1993. Tyranny and Political Culture in Ancient Greece, London and Ithaca: Cornell University Press.

Monoson, S. 1994. "Citizen as Erastes. Erotic Imagery and the Idea of Reciprocity in the Periclean Funeral Oration," Political Theory 22, $\mathrm{n}^{\circ}$ 2, 253-276.

Newell, W. R. 2000. Ruling Passion. The Erotics of Statecraft in Platonic Political Philosophy, Lanham, MD: Rowman \& Littlefield Publishers.

- 1983. "Tyranny and the Science of Ruling in Xenophon's Education of Cyrus," Journal of Politics, 45, 889-906.

Ober, J. 2003. "Tyrant killing as Therapeutic Stasis, A Political Debate in Images and Texts," Popular Tyranny, K. A. Morgan (ed.), Austin: University of Texas Press, 215-251. 
O'Connor, D. K. 2007. "Rewriting the Poets in Plato's Characters," in The Cambridge Companion to Plato's Republic, G. R. F. Ferrari (ed.), Cambridge: Cambridge University Press, 55-89.

Palmer, M. 1982. "Alcibiades and the Question of Tyranny in Thucydides," Canadian Journal of Political Science, Vol. 15, No. 21, 103-124.

Parry, R. D. 2007. "The Unhappy Tyrant and the Craft of Inner Rule," in The Cambridge Companion to Plato's Republic, ed. G. R. F. Ferrari, Cambridge: Cambridge University Press.

Plato. 1951. The Symposium, transl. by W. Hamilton: Penguin Books.

_ 1997. Plato. Complete Works, ed. J. M. Cooper and D. S. Hutchison, Indianapolis and Cambridge: Hackett Publisher.

- 2004. Republic, C. D. C. Reeve (tr.), Indianapolis and Cambridge: Hackett Publishing.

Plutarch. 1909. Life of Alcibiades, Plutarch's Lives: Part 12, Harvard Classics, in Dryden's transliteration corrected and revised by A. H. Clough, New York: Collier \& Sons.

Raaflaub, K. A. 2003. "Stick and Glue: The Function of Tyranny in Fifth-Century Athenian Democracy," Popular Tyranny: Sovereignty and Its Discontents in Ancient Greece, Austin: University of Texas Press, 59-93.

Romilly, J. de. 1995. Alcibiade, ou les dangers de l'ambition. Paris: Editions de Fallois.

Rosen, S. 2005. Plato's Republic: a Study, New Haven and London: Yale University Press.

Schmitt-Pantel, P. 1979. "Histoire de tyran ou comment la cité grecque construit ses marges," Les Marginaux et les exclus de l'histoire, Paris, Cahiers Jussieu 5, 217-231.

Scott, D. 2007. "Eros, philosophy, and tyranny," in Maieusis: Essays in Ancient Philosophy in Honour of Myles Burnyeat, ed. Dominic Scott, Oxford: Oxford University Press, 136-153.

Seager, R. 1967. "Alcibiades and the Charge of Aiming at Tyranny," Historia, XVI/1, 6-18.

Strauss, B. 1993. Fathers and Sons in Athens: Ideology and Society in the Era of the Peloponnesian War. Princeton: Princeton University Press.

Strauss, L. 2000. On Tyranny, Chicago and London: University of Chicago Press.

Thucydides. 2009. The Peloponnesian War, Trans. by M. Hammond, Oxford World's Classics: Oxford University Press.

Wohl, V. 2002. Love Among the Ruins: the Erotics of Democracy in Classical Athens, Princeton and London: Princeton University Press.

- 1999. The Eros of Alcibiades, in Classical Antiquity, vol. 18, no. 2, 349-385. 